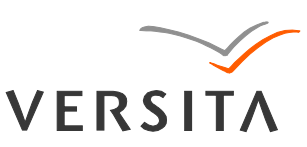

GEOCHRONOMETRIA 41(4) 2014: 377-391

DOI 10.2478/s13386-013-0172-z

Available online at

www.springerlink.com

\title{
THE REFLECTION OF HUMAN ACTIVITY IN THE SEDIMENTS OF IWANKOWSKIE LAKE FROM SUBATLANTIC PHASE (POLISH OUTER CARPATHIANS)
}

\author{
ANNA BUCAŁA ${ }^{1}$, WLODZIMIERZ MARGIELEWSKI ${ }^{2}$, LESZEK STARKEL ${ }^{1}$, KRZYSZTOF BUCZEK $^{2}$ \\ and VALENTINA ZERNITSKAYA ${ }^{3}$ \\ ${ }^{1}$ Institute of Geography and Spatial Organizations, Polish Academy of Sciences, Department of Geoenvironmental Research, \\ Św. Jana 22, 31-018 Kraków, Poland \\ ${ }^{2}$ Institute of Nature Conservation, Polish Academy of Science, A. Mickiewicza 33, 31-120 Kraków, Poland \\ ${ }^{3}$ Institute for Natural Management, NAS of Belarus, F. Skorynu Str. 10, 220114 Minsk, Belarus
}

Received 30 December 2013

Accepted 3 July 2014

\begin{abstract}
The paper presents the analysis of organic and mineral sediments filling the depression, which developed over the landslide located at the slope (767-773 $\mathrm{m}$ a.s.1.) of Lubań ridge decscending to the Ochotnica river valley in the Polish Flysch Carpathians. The landslide formed in an early stage of the Subatlantic Phase $(2490 \pm 35 \mathrm{BP})$. The top of peat is dated at $1360 \pm 50$ years BP and is covered by $72 \mathrm{~cm}$ of clayey silts with some sandy intercalations, which indicate slopewash after deforestation. The pollen of ruderal plants and Cerealia (undiff.) reflect agricultural activity in the surroundings. The fragments of charcoal indicate the age of the forest clearance to the first half of the $17^{\text {th }}$ century. The late forest clearance at the elevated north exposed slopes followed 200-300 years later in relation to the foundation of the village at the valley floor.
\end{abstract}

Keywords: landslide peat bog, palaeoenvironmental interpretation, human activity, Subatlantic Phase, Lubań Range, Polish Outer Carpathians.

\section{INTRODUCTION}

Depressions that occur over landslide bodies are often filled with water and, thus, form landslide lakes (Nowalnicki, 1976; Margielewski, 2006). Being gradually overgrown with vegetation and filled with sediments, they form peat bogs. Unique sedimentary environment and abrupt hydrologic changes, which are typical of landslide terrains, give those types of bogs the name - landslide peat bogs (Margielewski, 2006; Obidowicz and Margielewski, 2008; Margielewski et al., 2010a, 2010b). Deposits of such peat bogs are sensitive indicators of changes of the Carpathian

Corresponding author: A. Bucała

e-mail: abucala@zg.pan.krakow.pl palaeoenvironment. The sedimentary environment of the landslide peat bogs used to respond quickly to increasing humidity of climate as well as to human impact. As a result of mineral sediment supply to the sag ponds, peat can be altered with mineral and illuvial horizons, or mineral covers can overtop the peat. In the sedimentary core there are hiatuses which are effects of the lake draining as well as erosional removal of sediments (Margielewski, 2006; Margielewski et al., 2010b). Pollen analysis of the peat make it possible to reconstruct changes in plant communities surrounding the area. These changes allow for identification of cool and humid climate phases as well as stages of human activity (Gil et al., 1974; Margielewski, 2006; Margielewski et al., 2010a, 2010b). 
Transformation of landslide terrains by humans was associated with attractiveness of flattened slope sections (accessible water and fertile soils) for settlement (Margielewski, 2000 and 2006). Owing to forest burning and subsequent farming intensification, mineral sediments were washed from the slopes and supplied to peat bogs (especially those developed on flattened hillsides), therefore, environmental changes were registered in them (see Starkel, 1988; 1989; Margielewski, 2006; Brown, 2009).

The studied mire called Iwankowskie Lake (seasonal lake) in the Lubań Range (the Outer Carpathians, Gorce Mts.) exemplifies a landslide peat bog in which changes of the palaeoenvironment of the Carpathians are registered. The lake is found in a mountain range, which has been weakly recognized until now with respect to palaeoenvironmental changes. In the Gorce Mts., only one site raised bog on the Kiczora Mt. formed during Subatlantic was palynologically analyzed in detail till now, but without radiocarbon age determinations (see Koperowa, 1962). However many profiles of peat bogs that occur in the vicinity of the Gorce Mts. were paleobotanically elaborated; the results of palaeoenvoronmental analyses are not comparative with Iwankowskie Lake, due to a rather different climate, relief, hydrography, as well as human impact on the palaeoenvironment. Most of them are located in the Orawa-Nowy Targ Basin which occurs on the south of the Luban Range, at the foot of the Gorce Mts. (see: Koperowa, 1962; Obidowicz, 1989; 1990; Kołaczek et al., 2010).

The area of the Gorce Mts. showed settlements starting from the $13^{\text {th }}$ century, but the inflow of population of Balkan origin at the turn of the $14^{\text {th }}$ and $15^{\text {th }}$ centuries played an important role in the settlement in this region (Czajka, 1987).

The purpose of this paper is to express the detailed analysis of the deposits filling the depression formed over the landslide at the beginning of the Subatlantic Phase as well as the identification of timing and scale of human impact on the natural environment in this part of the Carpathians based on approximate data as pollen analysis, sedimentological, and loss on ignition. Non-pollen palynomorphs were only analyzed additionally: this analysis only supports the interpretation of palaeoenvironment based on pollen spectra.

\section{STUDY AREA}

\section{Geological and geomorphological setting}

Iwankowkie Lake fills a depression, which formed in a landslide affected area developed on the northern slopes of the Luban Range. That mountain range descends to the valley floor where the village of Ochotnica Gorna is located (the Western Outer Carpathians; N49 30'120"; E020 15'108”, $772 \mathrm{~m}$ a.s.1.) (Fig. 1). The Lubań Range is located in the zone of Krynica Subunit (Magura Nappe). Tylmanowa syncline, built of massive Magura sandstones of the Magura Formation (with two lithostrat- igraphic members: sandstones of Piwniczna and Poprad Members) is the major geologic structure here (Burtan et al., 1978; Paul, 1980). The landslide zone developed over the Poprad Sandstones Member - massive sandstones interbedded with thin shales. The sandstones of Piwniczna member occur at the base of the landslide zone and are represented by massive sandstones or conglomeratic sandstones with shale inserts (Burtan et al., 1978; Paul, 1980; Kulka et al., 1987).

The Luban Range (1211 m a.s.1.), whose orientation follows a parallel of latitude, is separated from the Gorce Range by a deeply incised valley of the Ochotnica River. Southward, the Lubań Range descends in a step-like pattern towards Nowy Targ Basin and the Krośnica River valley, and there borders the Pieniny Klippen Belt. In the east, the Luban Range is separated from the Radziejowa Range (Beskid Sądecki Mts.) by the antecedent gorge of the Dunajec River (Starkel, 1972; Zuchiewicz, 2010). Passes and deep V-shaped valleys dissect the 600-800 m high ridges of the Lubań Range.

Convex slopes prevail on the northern sides of the Lubań Range. The lower parts of the slopes are steeper. Flattened ridges (780-820 $\mathrm{m}$ a.s.1.), with inclinations of $5-10^{\circ}$, occur among deeply incised valleys (with valleysides sloping at $25-30^{\circ}$ ). The landslide, being subject of study, is located at the above-mentioned elevations. The deforested, flattened ridges have been under cultivation for many years, which is evidenced by a cadastre map of 1846 showing borders of lots and forests. Those borders did not change significantly. Deforested parts, apart from flattened sections, also occur on gentler foothills and on interfluves (Fig. 2).

\section{Climate and vegetation}

The Luban Range is located in a cool humid temperate climatic vertical zone with an average temperature of $4-6^{\circ} \mathrm{C}$ (Hess, 1965). Mean annual precipitation registered at the outlet of the Jaszcze stream valley (left tributary of the Ochotnica River - $c a .4 \mathrm{~km}$ north of Iwankowskie Lake - $610 \mathrm{~m}$ a.s.l.) for the period of 1958-2008 was $841 \mathrm{~mm}$ (Bucała, 2012). Mean annual air temperature decreases from $6^{\circ} \mathrm{C}$ at the Ochotnica valley floor to $3^{\circ} \mathrm{C}$ on top of the ridges (Obrębska-Starklowa, 1969).

Topoclimatic studies performed in the neighbouring valleys of the Jaszcze and Jamne streams (left tributaries of the Ochotnica River, ca. 4-10 km north of Iwankowskie Lake) provide evidence that the warmest zone occurs at elevations of 100-120 m above the valley floors, which are subjected to temperature inversions. Melting of snow cover is related to aspect of the slopes. As results from the studies in the Jaszcze and Jamne valleys, the snow cover first disappears from the south-facing slopes, therefore the vegetation period is longer there (ObrębskaStarklowa, 1969). The north-facing slopes are rather unfavourable for cultivation, and their deforestation was likely to take place later. Cultivation of cereal, bulb and root plants was possible only on flattened ridges from 

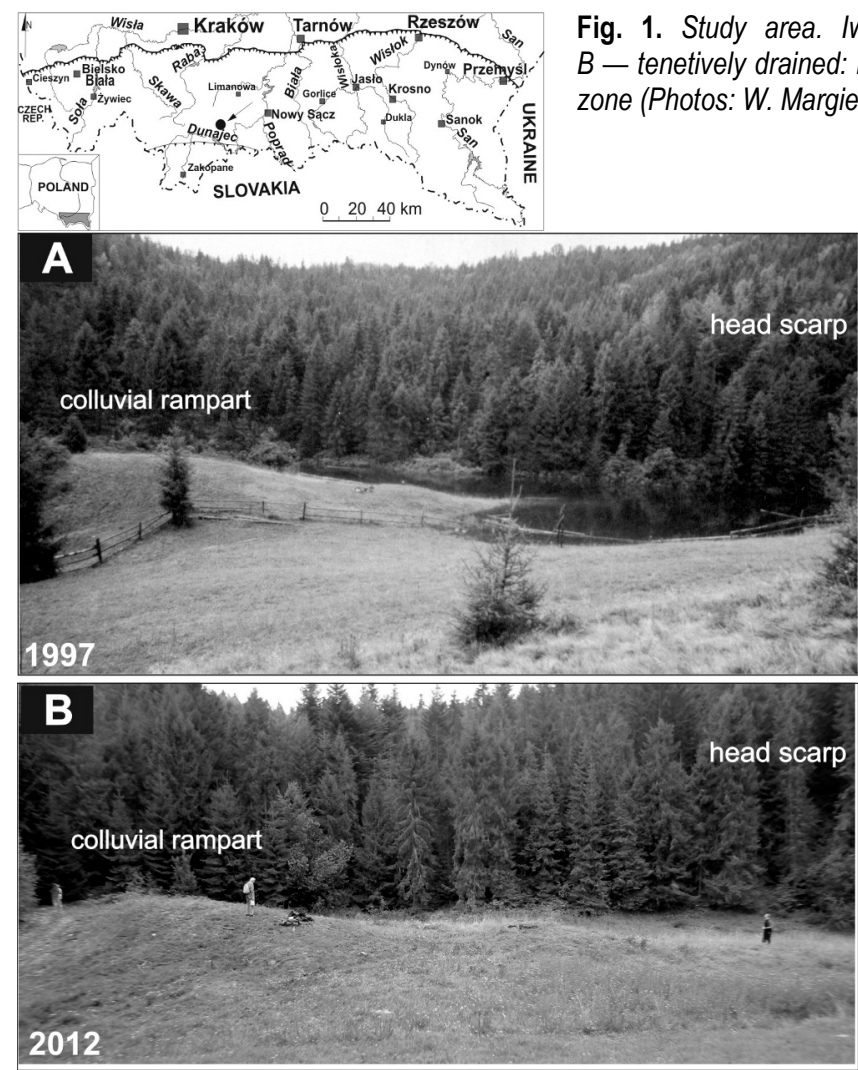

Fing
Fig. 1. Study area. Iwankowskie Lake: A - filled with water after precipitation in 1997; $B$ - tenetively drained: mire surface visible, $C$ - orthogonal projection of hypsometry of landslide

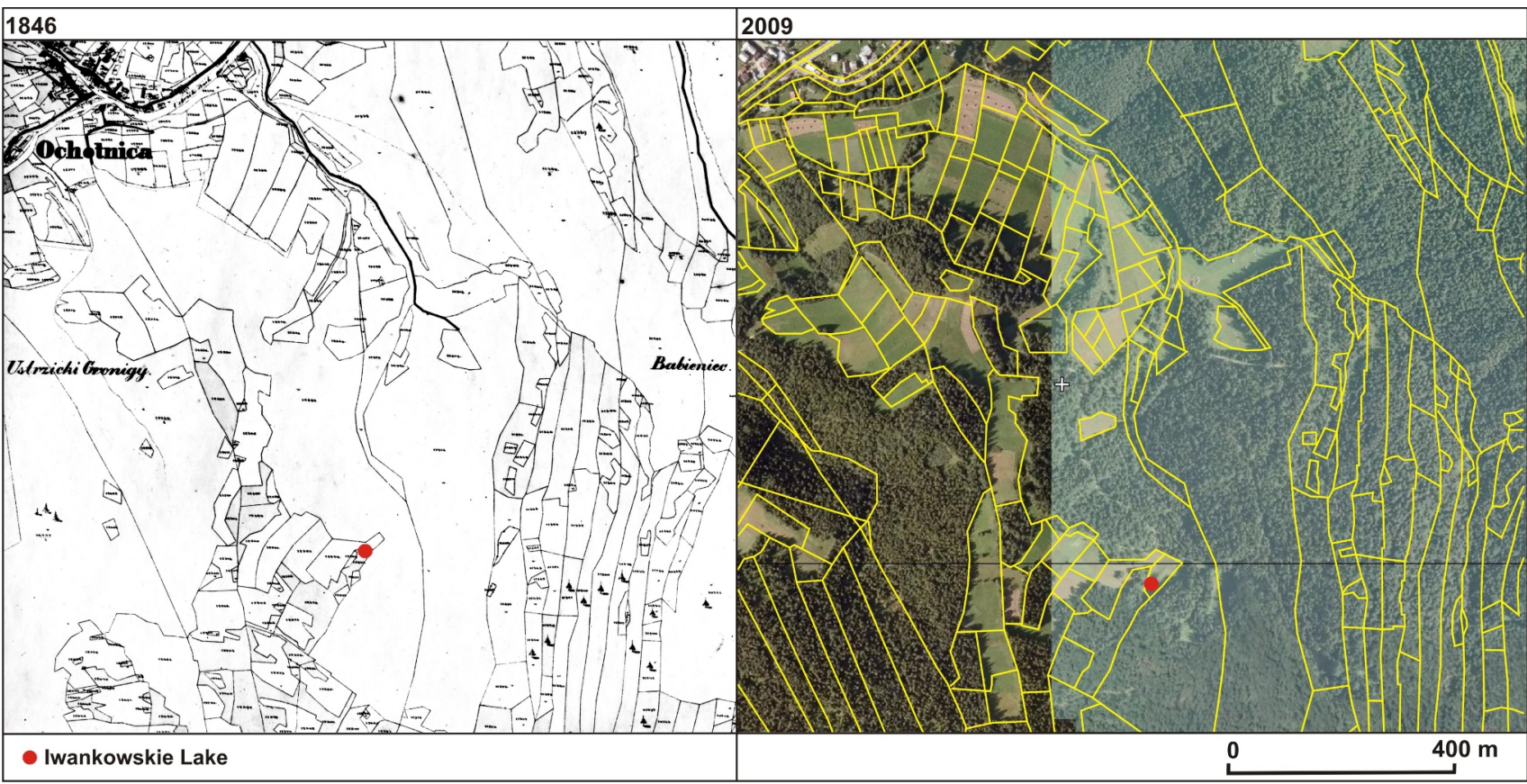

Fig. 2. Cadastre maps of 1846 and 2009 with present-day land use as the background (source: National Archive in Cracow, Division V, www.geoportal.gov.pl). 
which the snow cover was wind-blown earlier than from the surroundings (Obrębska-Starklowa, 1969).

In the area of the Luban Range, skeletal brown soils prevail. The soils are present on the slope covers developed on the Magura sandstones (Adamczyk and Komornicki, 1969). The analyzed area is overgrown with forest communities, especially those of a deciduous and mixedtree forest vertical zone, while the Carpathian spruce forests occur only at elevations above $1000 \mathrm{~m}$ (Medwecka-Kornaś, 1968).

\section{LANDSLIDE DESCRIPTION}

The landslide zone ( $c a .15$ ha in area), in which Iwankowksie Lake is present, was formed in a few stages as a result of mass movements affecting the headwater area of the right tributary of the Ochotnica River. Generally, the direction of gravitational dislocations was opposite to dipping of the beds (Margielewski, 1997). The landslides, which formed here, were rotational slumps according to the classification of Dikau et al. (1996).

The older landslides covered the sub-summit parts of the Runek Hubieński ridge. The present landslide zone is the effect of rejuvenation by successive generations of mass movements, and the developed, $30 \mathrm{~m}$ high, scarp delimits the eastern margin of the zone. A large elongated basin (125 $\mathrm{m}$ long and $42 \mathrm{~m}$ wide), dammed in the west by a $4 \mathrm{~m}$ high colluvium ridge, was formed at the foot of the scarp. At present the basin is filled with peat bog sediments, but water filling it periodically makes a picturesque Zawadowskie Lake (see Fig. 1) (Nowalnicki, 1976; Margielewski, 1997). Due to rejuvenation of the western landslide zone by a younger generation of mass movements, a subsequent landslide with an amphitheatre, $15 \mathrm{~m}$ high, main scarp and characteristic Lake at the scarp base were formed. The basin, dammed from the north by a series of colluvial ridges, is also filled with peat bog sediments and periodically with water (up to $2 \mathrm{~m}$ deep), thus, forming Iwankowskie Lake (the water table of this lake is a few meters below Zawadowskie Lake). A characteristic, heart-like shape of the lake is a result of a slide of the colluvial ridge into the basin. In effect, the outflow from the basin was dammed (Fig. 3) (Margielewski, 1997). Water is drained from the ponds by a subsurface system: at the base of colluvial ridges damming the outflow towards the north, a spring zone of the tributary of the Ochotnica River, was formed (Fig. 3).

Depression, in which Iwankowskie Lake occurs, is filled with peat bog sediments reaching a thickness of $2.5 \mathrm{~m}$ at the deepest point (Fig. 4). In the southern part of the peat bog, at the outlet of the main scarp incision, an alluvial fan developed which covered the peat surface at this point. The profile of the peat bog was subject to detailed sedimentological and palynological analyses (Figs. 5 and 6$)$.

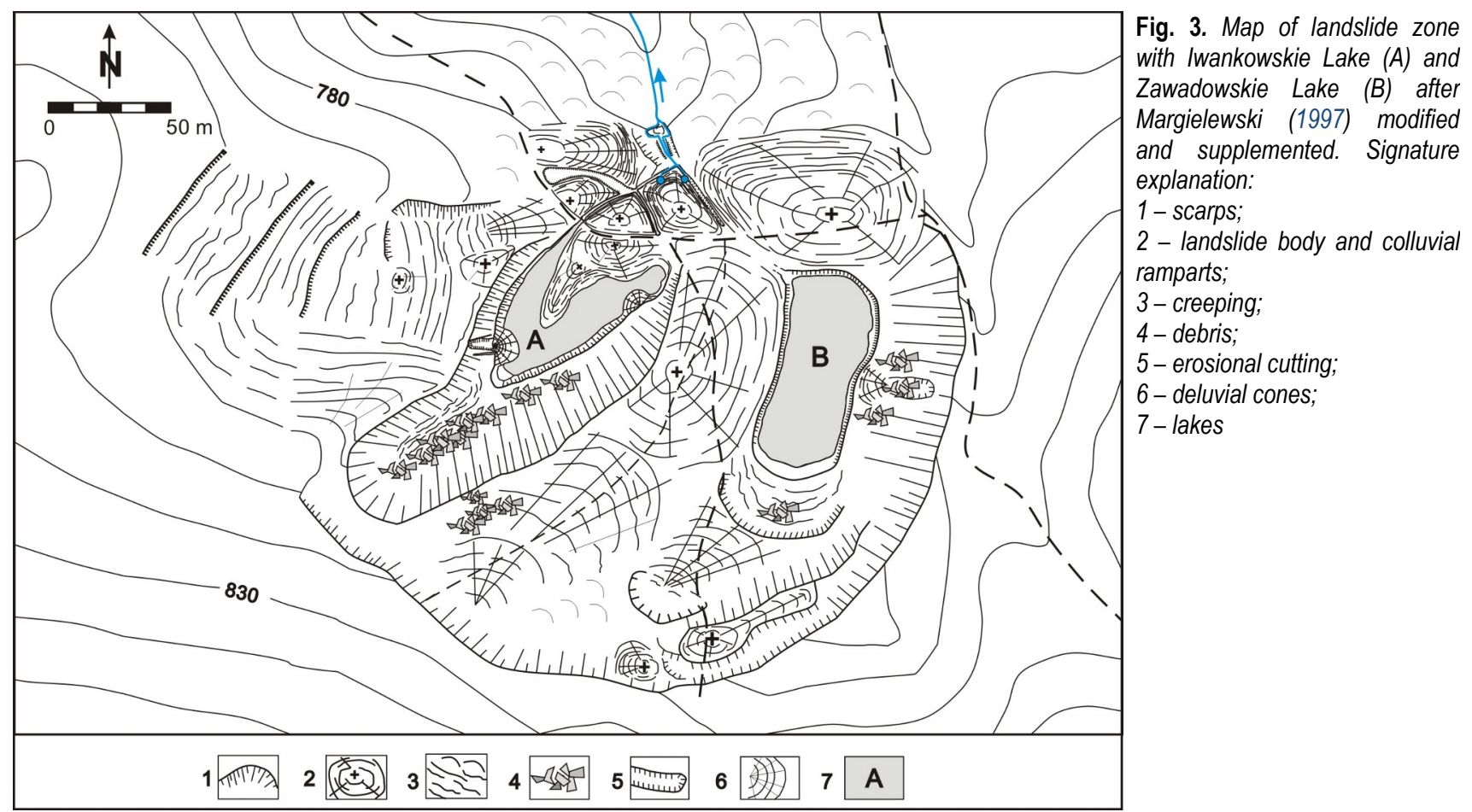


A. Bucała et al.

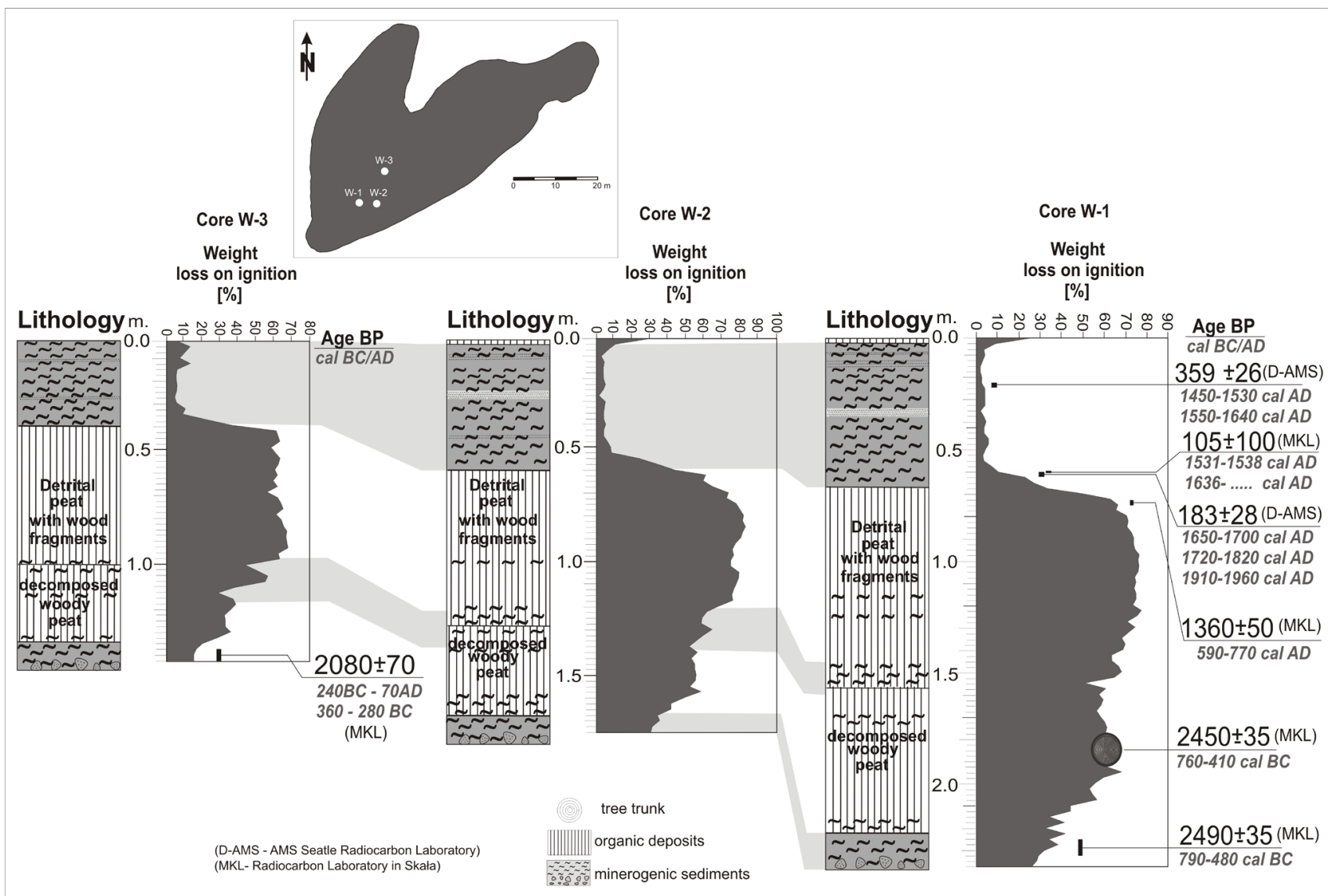

Fig. 4. Sediment cores sampled from different parts of the peat bog in Iwankowskie Lake basin, curves of loss on ignition and radiocarbon age determinations. Above - location of boreholes (cores) (lithological analysis: by W. Margielewski and K. Buczek).

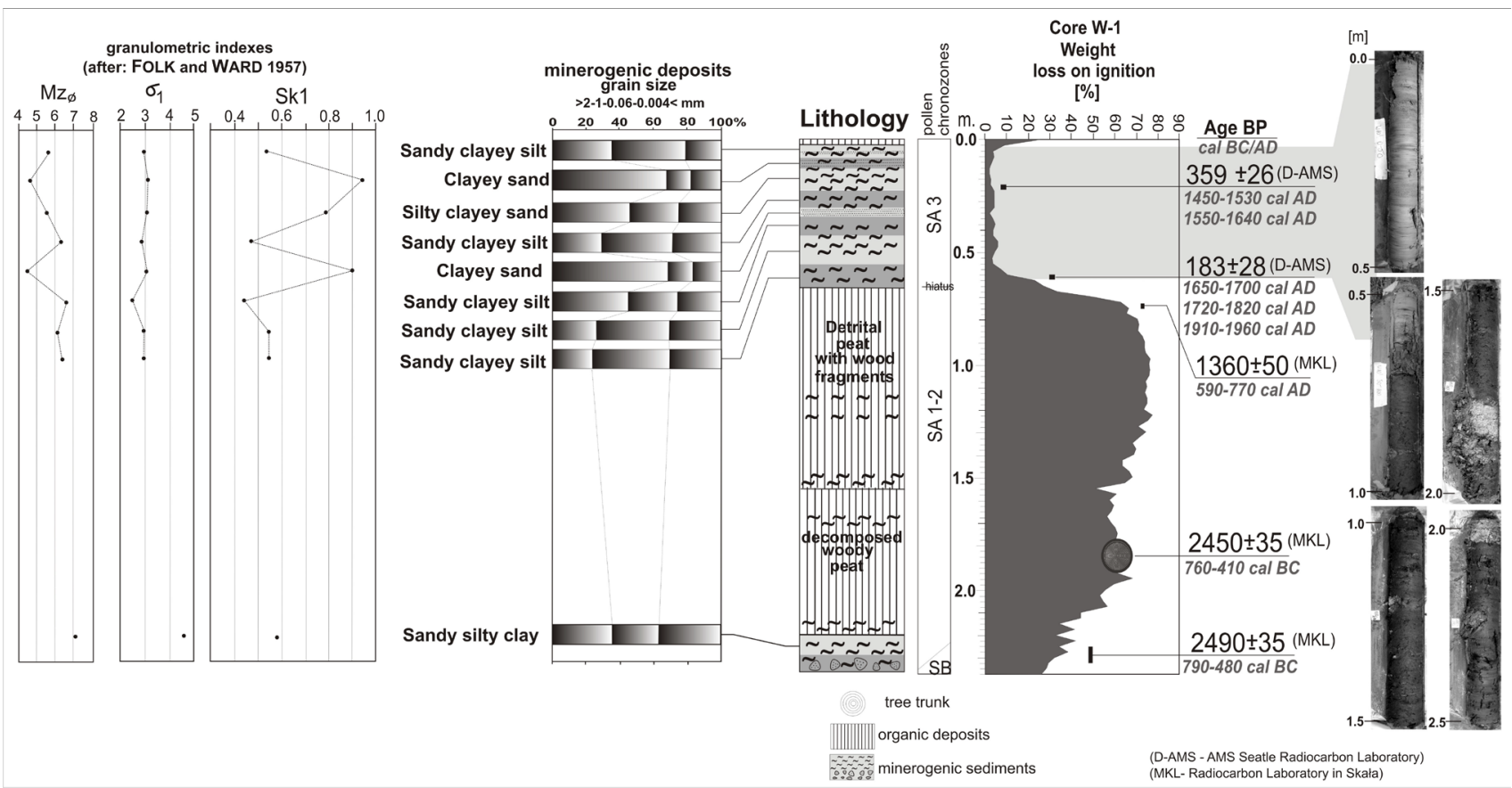

Fig. 5. Lithologic profile of mire deposits in Iwankowskie Lake basin, curve of loss on ignition, grain-size analysis (anal. W. Margielewski and K. Buczek). On the right-hand-side - photos of particular sequences of the sediments sampled with INSTORF sampler (photo: W. Margielewski). 


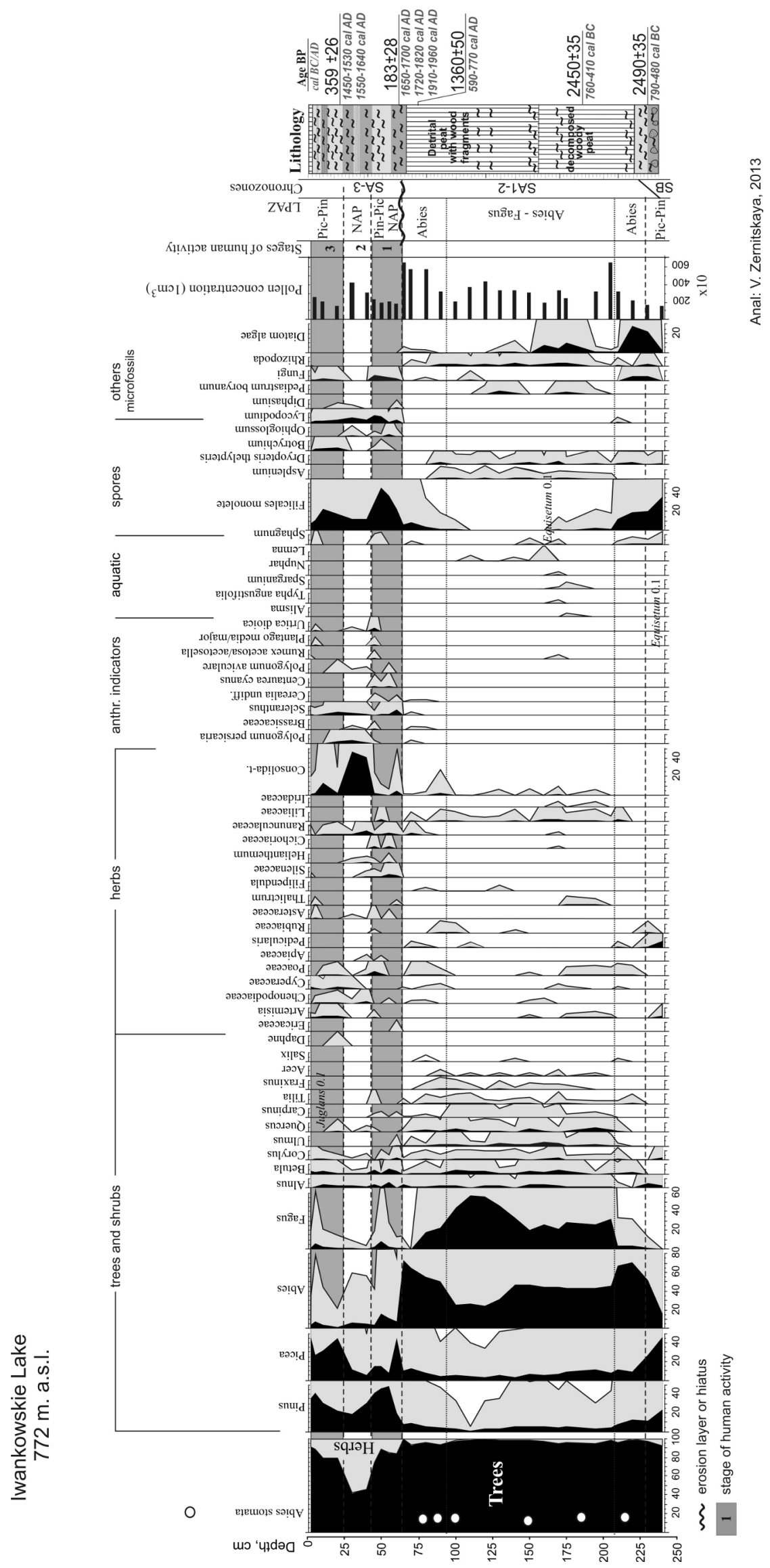

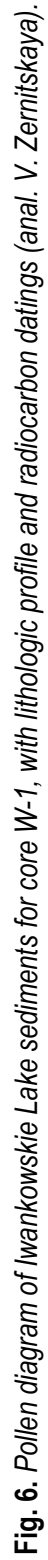




\section{OUTLINE OF HUMAN SETTLEMENT HISTORY}

The Lubań Range in the Gorce Mts. (where Iwankowskie Lake occurs) together with the Ochotnica valley is located between two settlements: Orawa-Nowy Targ Basin in the west and Nowy Sącz Basin in the east. These centres were settled already in the Late Palaeolithic and Neolithic (Valde-Nowak, 1988, 1995, 2000). The basins are connected by a transportation route, namely the Dunajec and Krośnica Rivers. (Ochotnica River flows into the Dunajec).

In the Luban Range and in the Gorce Mts. there were no intensive settlements until the Middle Ages. The analysis is difficult because pollen diagrams from the Gorce Mts. are almost absent: in the pollen diagram from the Kiczora Mt. in Turbacz Mt. massif ( $c a .9 \mathrm{~km}$ north of Iwankowskie Lake), cultivated plants (Cerealia undiff.) occur just since $\mathrm{ca}$. the $17^{\text {th }}$ Century (Koperowa, 1962). However, an early settlement in the nearby Nowy Sacz Basin, attributed to the Púchov Culture (Podegrodzie) of the La Tène Culture is known, whereas in the Orawa Nowy Targ Basin (area at the suth-west of Gorce Mts.) the settlement was developed in the Late Palaeolihic and Early Bronze Eppochs (Valde-Nowak, 1988). Moreover, a slightly later settlement of Przeworsk Culture in the Nowy Sącz Basin was intense (ca. 200 BC - AD 450) (Tunia, 1992; Madyda-Legutko, 1996). A decline in the settling process was observed during great migrations associated with invasion of the Huns in Middle Europe during the so-called Migration Period (AD 375-550) (Madyda-Legutko and Tunia, 1993). A few traces of settlements of that period are confirmed only from the sites located at higher elevations in the Poprad drainage basin (Madyda-Legutko, 1996). A new settlement cycle likely started in the Polish Carpathians in the $5^{\text {th }}-6^{\text {th }}$ century and was related to Slavonic settlements of the socalled Prague Province Culture (Parczewski, 1988). Early-Slavonic settlements with ceramics of Prague traits are also confirmed in the Nowy Sacz Basin (MadydaLegutko, 1996).

Intense settlements in the Gorce area did not take place earlier than in the $13^{\text {th }}$ century and was registered in written documents (see: Czajka, 1987). Wietrznica was the oldest village located near the outlet of the Ochotnica River to Dunajec valley. The village existed since 1285 as the property of Ordo Sanctae Clarae of Stary Sącz. Settling on German law was vivid in the south-eastern part of the Gorce and promoted formation of settlements on greenfield (Kamienica: AD 1334, Tylmanowa: AD 1336, Maniowy: AD 1326, Dębno: AD 1325, Szlembark, Harklowa: AD 1325, Grywałd: AD 1330, and town of Krościenko: AD 1348) (Czajka, 1987).

The oldest notes on Ochotnica are of 1336 and originate from Tylmanowa foundation documents, but the village gained the foundation privileges on 20 March 1416. King Władysław Jagiełło granted the privileges to Dawid Wołoch (Czajka, 1987).
At the end of $14^{\text {th }}$ and beginning of $15^{\text {th }}$ centuries, immigration of Balkan origin people - the Wallachians - played an important role in settlement of the Gorce. Ochotnica is considered to be the most important settlement there (Kurzeja, 2006). Wallachian shepherds, who came with sheep and goat flocks in the Gorce region from the south in search for pasture, cleared and burned the forests, set up fields and built new settlements. It is likely that the village of Babieniec was already formed in the $15^{\text {th }}$ century in the upper course of the Ochotnica River. From 1910, the village has gone by the name of Ochotnica Górna. The document of Babieniec foundation on Walachian law is not known. The name of this settlement appears for the first time in church documents in 1608. At present, the only trace of the name Babieniec in the area of Ochotnica Górna is the name of the summit - Wierch Babiniec (Czajka, 1987). The best period of pasturing in Ochotnica was in the $16^{\text {th }}$ and $17^{\text {th }}$ centuries. However, infertile soils did not support inhabitants in developing farming. Thus, for subsistence it was natural to combine plant cultivation with pasturing as well as with exploitation on fruits of undergrowth (Czajka, 1987; Adamczyk, 1996). With time, however, under demographic pressure, pastureland (and intra-forest glades) were converted into arable land. This phenomenon took place by the end of $17^{\text {th }}$ century and contributed to a gradual ceasing of pasturing (Dobrowolski, 1936; Flizak, 1966). With growing overpopulation, a process of splitting homesteads and partitioning of arable lands was accelerated.

Ochotnica was a forest-plot village (Waldhufendorf Saxon settlement), with tripartite land lots. Two parts of each lot were forest cleared. Homesteads were located on both sides of the road running along the main valley. Fields, adjacent to homesteads, departed the main road sideways. Forest plots formed the outermost part of the lot belonging to the same owner. Forests, which extended to the summit parts of the ridges or watershed divides, formed the village borders. Forests plots were of different widths and lengths in relation to physiographic features. According to the cadastre map of 1846 , the village was divided in numerous hamlets, typically with patchy arable land. Farming expansion on slopes, where physiography and climatic conditions were less favourable, took place probably in the period of population growth and stronger demand for land $\left(17^{\text {th }}\right.$ and $18^{\text {th }}$ centuries) (Bucała, 2012, 2014).

As a result of overpopulation in the mountains, the farmland was strongly partitioned, so a shift of agricultural-forest limit even to elevations exceeding $1000 \mathrm{~m}$ a.s.l. as in Podhale (Górz, 1994; Górka, 1995) was observed.

The cadastre maps of the study area of 1846 and 2009 show similar pattern of land plots, which were usually subjected to further subdivision. Because of that, the forest was sometimes converted into arable lands or pastures. At lower elevations, deforestation progressed, while at higher locations (over $780 \mathrm{~m}$ a.s.l.) the plots were merged and some of them were even reforested (see Fig. 2). 


\section{MATERIALS AND METHODS}

The exploratory drilling campaign comprised 12 boreholes drilled in mires (peat bogs) using a spiral bit. Cores of sediments were taken with INSTORF sampler (Russian peat sampler), using core barrels $6-8 \mathrm{~cm}$ in diameter. For three cores taken from various parts of mire, analyses of loss on ignition were carried out. Complete palynological and aerometric analyses were performed for the longest core (Fig. 5 - core W1).

The cores were sampled in $2.5 \mathrm{~cm}$ thick intervals, and analysed for loss on ignition at a temperature of $550^{\circ} \mathrm{C}$ (in a furnace stove), according to the procedure proposed by Heiri et al. (2001). The Bouyoucos-Casagrande aerometric analysis, as modified by Pruszyński (MycielskaDowgiałło and Rutkowski Eds., 1995), was used for the examination of grain-sized composition of mineral sediments of the mires (peat bogs). Minerogenic deposits were classified according to Pettijohn's scheme (Pettijohn, 1975; Battaglia et al., 2002) combined with a grainsized scale of Wentworth (1922) Grain size indices: mean grain size $(\mathrm{Mz})$; standard deviation $(\sigma 1)$, and skewness (Sk1) were determined following Folk and Ward (1957) (Fig. 5).

Conventional radiocarbon dates (BP) were obtained in the Absolute Dating Laboratory in Skała (near Cracow) by M. Krąpiec whereas the AMS dating were carried out in the Seattle Radiocarbon Laboratory (USA). Calibrations of radiocarbon dates (expressed as cal BC/AD) were carried out using the calibration data set of Reimer et al., (2013) using the OxCal v. 4.2 computer program (Bronk Ramsey, 2009) (Table 1).

Results of pollen analysis are presented as a percentage of pollen diagrams, elaborated by V. Zernitskaya (Fig. 6). Palynological samples $\left(2 \mathrm{~cm}^{3}\right.$ of fresh sediment) were prepared according to the Erdtman (1943) (see also Berglund and Ralska-Jasiewiczowa, 1986) procedure.
Besides pollen quantity, the study included stomata of plant, fungi and rhizopoda (amoebae fauna). The percentage values were calculated on the basis of arboreal and non-arboreal pollen sum $\left(\sum \mathrm{AP}+\sum \mathrm{NAP}=100 \%\right)$, only excluding demonstrably aquatic taxa and spore plants. Percentages of aquatic pollen and ferns/mosses spores as well as of non-pollen palynomorphs were calculated on the basis of $\sum \mathrm{AP}+\sum \mathrm{NAP}+$ sum of corresponding grains $=100 \%$. Pollen and spore identification was based on Moore et al. (1991) and Reille (1992). The mean number of the terrestrial pollen was counted up to 500 grains/sample. The concentration of pollen is shown in $1 \mathrm{~cm}^{3}$ and varies between 1860-6200 (Kabailene, 1969). These data (with lithology) reveal the speed of sediment accumulation or stages of the high hydrological activity.

\section{RESULTS}

\section{Lithology}

The longest core was obtained from the central part of the mire (peat bog). At the base of the basin, in the $240-$ $211 \mathrm{~cm}$ interval, minerogenic deposits are blue or blueish-brown in colour and represented by sandy silty clay (Fig. 4 - core W1; Fig. 5). Fragments of wood and bark are numerous there. Wooden detritus sampled from the deposits at the depth of 233-224 cm was radiocarbon dated at $2490 \pm 35$ BP (790-480 cal BC) (MKL-1577). In the neighbouring borehole, located in the marginal part of the mire (peat bog) the dating of the base deposits is slightly younger $-2080 \pm 70 \mathrm{BP}(240 \mathrm{BC}-70 \mathrm{AD}$; 360-280 BC) (MKL-1579) (Fig. 4 - core W-3; Table 1). In the main core, a complex of organic deposits occurs above the bottom sediments at the depth of $211-72 \mathrm{~cm}$. Strongly decomposed peat is present at the base (at that interval of $211-200 \mathrm{~cm}$ ). Numerous pieces of wood as well as some fir needles are present in this peat. At the depth of $195-175 \mathrm{~cm}$ a piece of a tree trunk occurring in

Table 1. Radiocarbon datings of Iwankowskie Lake peat bog (calibration using OxCal v. 4.2. (Bronk Ramsey, 2009) on the base of Reimer et al., 2013 calibration curve).

\begin{tabular}{|c|c|c|c|c|c|}
\hline $\begin{array}{l}\text { Depth } \\
\text { (cm) }\end{array}$ & Material & Lab. Code & $\begin{array}{l}\text { Age }{ }^{14} \mathrm{C} \\
\text { (BP) }\end{array}$ & $\begin{array}{l}\text { Calibrated age } 2 \sigma \\
\text { (cal BC/AD) }\end{array}$ & Context of datings \\
\hline \multicolumn{6}{|c|}{$\log W-1$} \\
\hline $22.5-25$ & charcoal & D-AMS-2238 & $359 \pm 26$ & $\begin{array}{l}1450-1530 \mathrm{AD} \\
1550-1640 \mathrm{AD}\end{array}$ & Upper part of mineral level formation \\
\hline $60-62.5$ & charcoal & D-AMS-2237 & $183 \pm 28$ & $\begin{array}{l}1650-1700 \mathrm{AD} \\
1720-1820 \mathrm{AD} \\
1910-1960 \mathrm{AD}\end{array}$ & mineral cover on peat formation \\
\hline $77-75$ & wood detritus & MKL-1580 & $1360 \pm 50$ & $590-770 \mathrm{AD}$ & Top part of peat accumulation \\
\hline $175-179$ & Tree trunk & MKL-1578 & $2450 \pm 35$ & $760-410 \mathrm{BC}$ & $\begin{array}{c}\text { Formation of depression } \\
\text { (and landslide) }\end{array}$ \\
\hline 224-233 & Woody bark & MKL-1577 & $2490 \pm 35$ & $790-480 \mathrm{BC}$ & $\begin{array}{c}\text { Formation of depression } \\
\text { (and landslide) }\end{array}$ \\
\hline \multicolumn{6}{|c|}{$\log W-3$} \\
\hline $137-145$ & Wood fragments & MKL-1579 & $2080 \pm 70$ & $\begin{array}{c}240 \mathrm{BC}-70 \mathrm{AD} \\
360-280 \mathrm{BC} \\
\end{array}$ & Start of peat sedentation \\
\hline
\end{tabular}


the peat was drilled. According to the dendrological analysis performed by Prof. M. Krąpiec of AGH University of Science and Technology in Kraków, the tree piece was indicated as beech (pers. comm.). The wood piece sampled from the trunk was radiocarbon dated at $2450 \pm 35$ BP (760-410 cal BP) (MKL-1578). This date is synchronous with the dated fragments of bark and wood found in the deposits sealing the basin (Fig. 5).

In the $200-150 \mathrm{~cm}$ interval, in which a tree trunk was drilled, there is a horizon of decomposed tree peat, brown in colour, which contains a large amount of decomposed wood. The top of this complex $(170-150 \mathrm{~cm})$ is enriched with mineral sediments. There, at the depth of $150 \mathrm{~cm}$, a beech nut was found. The overlying peat, found in the interval of $150-72 \mathrm{~cm}$, is detrital, slightly decomposed, and contains numerous fragments of wood (it represents woody peat). This peat is characterized by a high loss on ignition reaching $75-80 \%$ (Fig. 5).

The peat is covered with $72 \mathrm{~cm}$ thick mineral sediments, which are results of allochtonous material supply to the mire (peat bog) mainly from a deluvial cone which, at present-day, mantles the mire. The mineral sediment cover is formed generally by sandy clayey silt which is polory sorted $(\sigma 1=c a$. 3). Some horizons of the deposits show stripes. Charcoal is present in places. Areometric analyses provide evidence that sandy clayey silt was enriched with more coarse (sandy) material periodically. Inserts of clayey sand occur in the intervals of 53-56; 3237 and 11-16 cm (Fig. 5). Those inserts can be either the records of extreme, repetitive downpours or effects of material sorting in the alimentation area. So, sorting might refer to the material of the deluvial cone or to the material resting on slopes (that material was supplied to the basin due to slopewash - see Margielewski, 2006). The top part of the cover (the topmost $5 \mathrm{~cm}$ ) is enriched with organic material.

The sample taken from the top of peat covered with mineral deposits $(77-75 \mathrm{~cm})$ was radiocarbon dated at $1360 \pm 50$ BP (590-770 cal AD) (MKL-1580). Then, the piece of charcoal occurring at the base of the cover was AMS dated at $183 \pm 28 \mathrm{BP}$ ( $c a .1650-1960 \mathrm{cal}$ AD) (DAMS-2237), and the wooden detritus sampled from the horizon of $59 \mathrm{~cm}$ (from the wall of the pit dug in the sag pond sediments) was dated at $105 \pm 100 \mathrm{BP}$ (1531-1538; $1636-\ldots$ cal AD) (MKL-1998). This significant age difference provides evidence for a hiatus at the base of the cover. This is definitely confirmed by palynological analysis (Fig. 6). A piece of charcoal, occurring in the upper parts of the cover $(25 \mathrm{~cm})$ was dated at $359 \pm 26 \mathrm{BP}$ (1450-1530; 1550-1640 cal AD) (D-AMS-2238) (Fig. 5).

\section{Vegetation history}

Pollen diagram was divided into local pollen assemblage zones (L PAZ) according to Birks (1979, 1986) (Fig. 6). The diagram was also divided into chronozones proposed by Mangerud et al. (1974), modified by Starkel et al. (2013).

\section{Local vegetation development}

The Picea-Pinus LPAZ $(240-230 \mathrm{~cm})$ corresponds to the oldest Subatlantic chronozone, and to the Subboreal/Subatlantic transition acoording to Starkel et al. (2013), ca. between 2850-2400 cal BP (Fig. 6). The decreasing percentage values of Pinus (from 24 to $12 \%$ ) and Picea (from 46 to $23 \%$ ) pollen, as well as Corylus is typical for the termination of the Subboreal (RalskaJasiewiczowa et al. Eds, 2004) according to Mangerud et al. (1974). The increase of Abies alba (ca. 20\%) and immigration of Fagus sylvatica also indicate the transition to Subatlantic. Other characteristics are a higher share of fern (Filicales monolete) spores. The low pollen concentration in sandy clayey silt at the $230-240 \mathrm{~cm}$ depth indicates the fast accumulation of deposits.

The Abies LPAZ, Abies-Fagus and Abies LPAZ-s $(230-65 \mathrm{~cm})$ correspond to the older and middle part of Subatlantic chronozone $(\sim 2400-1000$ BP, according to Starkel, 1999). These LPAZ illustrates the distribution of shady natural beech-fir forests accompanied by broadleaves trees (Quercus, Ulmus, Carpinus). The Abies stomata are present constantly in sediments. The main maximum of Fagus-Abies forests in the NW Carpathians is set in the range 3000-1500 yr BP (Obidowicz et al., 2004; Latałowa et al., 2004) that confirms our chronology. Wetlands and boggy parts of surrounding territory were occupied by plants from family of Liliaceae and ferns such as Thelypteris palustris, Athyrium filix-femina. The aquatic and semiaquatic plants were submitted by Typha angustifolia, Alisma, Sparganium, Nuphar, Lemna, Pediastrum boryanum and by Diatom algae. The hydrohygrophytes (Centropyxis aculeate, Amphitrema flavum) and sphagnum species (Arcella) of amoebae were found. (Bobrov et al., 1999; Opravilovà and Hàjek, 2006). Reduction of Fagus pollen and weak increase of herbs (Poaceae, Cyperaceae, Ranunculus, Consolida type) together with presence of Cerealia undiff. and other anthropogenic indicators are established at the end of the middle Subatlantic (LPAZ Abies, 63-98 cm).

The Pinus-Picea-NAP and Picea-Pinus LPAZ correspond with youngest Subatlantic Chronozone. These zones reflect an abrupt change of vegetation which is marked in sediments at depth of the $65 \mathrm{~cm}$. The oscillations of pollen concentration define the fast accumulation in intervals $65-50,20-10 \mathrm{~cm}$. The charcoal pieces were found in sample at the depth of $20 \mathrm{~cm}$ only. The diagram shows the displacement of the sediment from the upper horizons to the $60-55 \mathrm{~m}$ depth. This inversion is confirmed by radiocarbon data, as well as by similar peaks of pollen (Picea, Pinus, Fagus, Abies, Betula, Consolida, Filicales monolete). Probably, the vegetation changes were related to climatic conditions and/or connected with human economic activity. The deforestation is illustrated by fall of the Abies and Fagus pollen, by sharp pollen peaks of Picea, Pinus and NAP (ca. 60\%) and by the increase of the Botrychium, Ophioglosum, Lycopodium, Diphasium and Filicales monolete spores. Among herbs 
the Consolida type predominated $(22-43 \mathrm{~cm})$. Herbs of this genus have a wide ecological range, prefer the open places (grasslands, open forest) and have important significance as an arable weed (Consolida regalis). Moreover, rise values of Chenopodiaceae and anthropogenic indicators.

\section{PALAEOCLIMATIC CHANGES AND HUMAN IMPACT ON ENVIRONMENT}

Radiocarbon dating and polynological analysis show that the depression, over the landslide, in which the peat bog developed and which was periodically filled with water (as Iwankowksie Lake), was formed during more humid phase at the Subboreal/Subatlantic transition. Distribution of the radiocarbon dating of the parts of the mire (peat bog) close to its base show that the dates can reflect a real time of the depression formation and, therefore, the age of the landslide over which the depression had formed (see Margielewski, 2006). It is symptomatic that the date obtained from the wooden detritus present in the mineral sediments as well as the date obtained from the tree trunk (beech) occurring at the base of the depression are identical within the accuracy limits (i.e. $2490 \pm 35$ and $2450 \pm 35$ BP) (Fig. 5). As the sedimentation took place just after the depression formation, the date also identified the timing of the landslide development because the depression occurs at the base of the landslide main scarp. In the surroundings of the depression, intensive washing processes affected fragmented colluvial material, which is characteristic of a newly formed landslide. In the pollen diagram the reduction of spruce forests and occurrence of fir is recorded, which is typical in this time in the Carpathians (Obidowicz et al., 2004). The turn of the Subboreal Phase and the beginning of the Subatlantic Phase were particularly humid (see Starkel, 1977; Starkel et al., 2013), so numerous and repetitive precipitation favoured the washing processes. The dated tree trunk at the base of the deposits was dropped into the depression newly formed. So, both the dates unambiguously indicated the timing of the landslide formation (and the depression occurring there) and are crucial for dating mass movements (see Margielewski, 1998 and 2006).

The mass movements, during which the depression filled with water of Iwankowskie Lake was formed, and which rejuvenated the landslide zone, were associated with cooler and more humid climate at the turn of the Subboreal and Subatlantic Phases. A cooling, which could be considered as a phase, resulted in advances of glaciers in the Alps (Goeschener 1 Phase - Bortenschlager, 1982) in the Scandinavian mountains (Karlen and Kuylenstierna, 1996) and in intensification of nival processes in the Ukrainain Carpathians (Kovalyukh et al., 1996). A more humid climate, being a pluvial equivalent of cooling at higher elevations (see Starkel, 1995), brought in effect intensified flooding in the upper Vistula
River drainage basin (Starkel et al., 1996; Starkel, 2002; Starkel et al., 2006), and a rise of water level in Alpine lakes (Magny, 1993) as well as in lakes of northern Poland (Ralska-Jasiewiczowa Ed., 1989). In the Carpathians, intensification of mass movements was registered at that time (Alexandrowicz, 1996, 1997; Starkel, 1997; Starkel et al., 2013; Margielewski, 1998; 2006; Panek et al., 2010, 2013). Wetter climate favoured intensified supply of material to sedimentary basins (landslide lakes), resulting in the formation of mineral horizons within the organic deposits (Baumgart-Kotarba and Kotarba 1993; Margielewski, 2006, Margielewski et al., 2010a, 2010b). At that time, intensification of mass movements was also observed in other mountains of Europe (Ballantyne, 2002; Dapples et al., 2002; Soldati et al., 2004).

The palynological analysis of deposits from the base parts point out a decrease in concentration of pollen of Pinus, Picea, Alnus and Corylus, which, provided expansion of fir, suggests climate cooling at that time (Fig. 6). However, it is symptomatic that the indices of permanent filling with water are not registered in the base parts of the profile. The only evidence of aquatic condition is presence of Diatom algae and hydro-hygrophytes amoebas (Fig. 6). So, it is very likely that the basin bottom was not sufficiently sealed. Pollen of aquatic plants (Nuphar, Lemna) and rush plant (Typha), appears (periodically) only at the depths of ca 170-160 cm and is accompanied by a mineral sediment supply, which results in the formation of illuvial horizon in the peat. This horizon is clearly visible on the curve of loss on ignition (Fig. 5). The above might suggest that a persistent body of water was present here for a relatively short time. Mineral sediments, in suspension, were supplied from the surrounding of the mire (peat bog) to this body of water.

Successive supply of mineral sediments, forming the mineral cover over the peat, to the body of water is visible at the depth from $72 \mathrm{~cm}$. The beginning of the mineral material supply to the mire took place above the horizon which was radiocarbon dated at $1360 \pm 50 \mathrm{BP}(590-770$ cal AD) (peat below mineral cover was dated). In the horizon $(75-77 \mathrm{~cm})$, which was radiocarbon dated, traces of cereal pollen (Cerealia undiff.) appear for the first time in the pollen diagram. Open terrains of the discussed time-period are recorded in the pollen diagram by an appearance of Poaceae, Ranunculaceae (meadows) and typical weeds which were the first sign of early farming, namely Polygonum persicaria, Scleranthus, Brassicaceae (Behre, 1981) (Fig. 6). A local decline in concentration of tree pollen at that period cannot be associate with an evident deforestation, which is difficult to identify based on a decrease in the trace concentration of pollen of Ulmus, Carpinus, Tilia, and Fraxinus. What is more, the evident decline in Fagus pollen is accompanied by a complementary increase in Abies (Fig. 6). Simultaneous appearance of cereal pollen and gradual supply of mineral 
sediments to the mire can suggest a change related to cultivation being introduced by humans.

The initial, gradually increasing, supply of allochtonous sediments to the mire (peat bog) (ca. 590-770 cal $\mathrm{AD}$ ), was terminated by a deposition of a durable thick mineral cover on peat, seems to correlate well with a commonly observed cooler and more humid climate at $c a$. AD 500-800, and its culmination at $c a$. AD 550 (Frenzel, 2000). Because of floods, oak trees had intensively fallen. The phase of oak falling was dendrochronologically dated at 425-625 AD (Krąpiec, 1992; Kalicki, Krąpiec, 1995; Starkel et al., 2013). Rise of the water level in sub-alpine lakes (Petit Maclu-2 Phase - Magny, 2004) or in northern Poland (Żurek and Pazdur, 1999) provides evidence of a more humid climate. In the Carpathians, intensified mass movements were registered at that time (Margielewski, 2006; Panek, et al., 2013). In mountain mires (peat bogs) mineral horizons were deposited (Margielewski and Kovalyukh, 2003; Margielewski, 2006).

The mineral cover on the peat is associated with slopewash and formation of the deluvial cone (Margielewski, 2006; Margielewski et al., 2010b) (see Fig. 3). Sandy inserts in relatively homogenous clastic material of the cone provide evidence for an increased overland flow. The base deposits of the cover, where the sandy inserts occur, are characterized by a fairly uniform grain size composition (Fig. 5). It cannot be excluded that at present, the sandy inserts are related to the location of the analysed profile over the cone. Lamination of the mineral sediments within the cover point out that the sandy clayey silt was deposited generally in an aquatic environment (from suspension). The lacking pollen of aquatic plants may provide evidence of a periodic nature of the body of water. The palynologically identified and confirmed by the radiocarbon dating hiatus, which occurs at the base of the cover, is likely an effect of erosional removal of some deposits from the cover (see Margielewski, 2006). Numerous charcoal pieces are present in the cover. The burning of forests at that time in order to prepare land for cultivation and pasturing is confirmed by the change in pollen spectrum in the palynological diagram. However, an abrupt decrease in tree pollen, visible in the diagram, is an effect of a break in sedimentation (Fig. 6). Subsequent occurrence of pollen associations characteristic of cultivated plants (Cerealia undiff.), arable weeds (Centaurea cyanus, Polygonum aviculare, Polygonum persicaria and Consolida type perhaps), ruderal communities (Urtica, Artemisia), meadow and/or pastures flora (Rununculaceae, Rumex acetosa, Plantago major, Cichoriaceae) is of tentative (or episodic) nature and provides evidence for frequent changes in land use: a shift from plant cultivation to pasturing. Taking into account that the site is located on the north-facing slope at the hinterland of the deeply incised narrow valley of the Ochotnica River (with frequent temperature inversions), the change in the land use, that was forced by environmental condi- tions and manifested in shrinking the cultivated land in favour of pasturage, seems reasonable. It should be emphasized, that despite the northern aspect of the site, which was unfavourable for cultivation, the areas nearby the analysed site had an important asset for settling and land management: they were rich in water. Consolida type, the species preferring open habitats and cultivated area, is a good indicator of the changes in land use. A particularly high concentration of pollen of that species in the palynological diagram and a simultaneous significant (temporary) decrease in concentration of tree pollen, as well as the lack of pollen of cultivated plants, can indicate a transitory renaturalization of open habitats owing to deforestation, which was followed by the next phase of cultivating plants on the sunlit slope in response to the increase in human population.

A temporal interval of the hiatus in the deposits of the mineral cover is a controversial issue. Radiocarbon dates (AMS and conventional ones) obtained from charcoal pieces sampled from the cover deposits are inversed in the profile which can be attributed to many causes, including charcoal redeposition as a major one. On the ground of three L PAZ phases in the profile interval comprising the mineral cover (Pinus-Picea-NAP; NAP; Picea-Pinus), as well as two phases of human activity (separated by a period without cultivation) which were palynologically registered, it is not likely that the en masse sedimentation was a rapid event (see Fig. 6). Only a rapid rate of sedimentation of the sandy inserts was confirmed palynologically at the depths of $65-50 \mathrm{~cm}$ and $20-10 \mathrm{~cm}$. A relatively long process of the cover deposition (250-300 years long) could have been proven by trends of the curves of species of tree pollen (Pinus, Picea, Abies) and their concentration which show temporary deforestation and a new, also temporary, regeneration of the forests during the deposition of the cover (Fig. 6).

\section{DISSCUSION}

The pollen of cereals, marked in the diagram as Cerealia undiff. (including Triticum- type (cereal), Avena type (oat) and Hordeum - type (barley), excluding Secale - see Okuniewska-Nowaczyk et al., 2004) usually is not transported over long distances, but at best it migrates from the valley bottoms to upper parts of the slopes due to convection (Obidowicz et al., Eds., 2014). Small amount of cereal pollen in the deposits is associated with the fact that the cereals, which are self-pollinating, generally produce little pollen, and are usually underrepresented in the pollen diagrams (OkuniewskaNowaczyk et al., 2004). Thus, the presence of cereal pollen in the sediments is usually associated with the land use in the surroundings of the investigated site.

The cereal pollen (Cerealia undiff.) occurs in the diagram for the first time in the deposits of the mineral cover below the hiatus and was radiocarbon dated (indirectly) at slightly older than $590-770 \mathrm{cal} \mathrm{AD}$. The cereal pollen is 
accompanied by segetal weed (Polygonum persicaria, Scleranthus) (Figs. 5-6). The discussed site is the one of a few that would confirm the traces of early-Slavonic settlements in the Gorce, likely of the Pargue cultural province which was also identified in Nowy Sącz Basin (Madyda-Legutko and Tunia, 1993; Madyda-Legutko, 1996). Moreover, it would be the trace of a new settlement period in the Carpathians, which followed the Migration Period of AD 370-550.

Whereas the sediment sequence and the dates of the base and middle sections of the profile show a continual stratigraphic succession, the date inversion of upper sections within the mineral cover above the hiatus may be difficult to interpret.

The analysis of the pollen associations in the sediments of the mineral cover (above the hiatus) allowed for identifying two distinct phases of human activity in the palynological diagram (Fig. 6). Two phases of human activity, separated by the period when cultivation was discontinued, are more pronounced although they were identified in the profile section above the sedimentary hiatus. These phases are as follows:

Stage 1 - introduction of early farming. This stage may be recognized by the appearance of the pollen of agricultural cereals (Cerealia undiff.) and segetal weeds (Centaurea cyanus, Polygonum persicaria, Scleranthus, Polygonum aviculare, Consolida type), as well as rise of curves of Poaceae and the dash of ruderal species (Chaenopodiaceae, Artemisia, Urtica) as well as plants of grazing meadows (Plantago media/major, Rumex acetosalacetosella, Ranunculaceae, Cichoriaceae). On the background of radiocarbon datings, this stage of human activity could have been related to the $17^{\text {th }}$ century Wallachian colonization of the Gorce (Czajka, 1987). It cannot be excluded that intensification of agricultural practices in the vicinity of the peat bog (proven by pollen of Cerealia undiff. in the polynological profile) coincided in time with a strong cooling and more humid climatic conditions of the Little Ice Age. That resulted in (or only strengthened) the changes in sedimentary environment of the mire (peat bog) causing an onset of deposition of the mineral cover on the peat - the process which has been ongoing until present (see Fig. 1A, see also Margielewski, 2006). Intensive agricultural activity at that time is shown by the appearance of Funghi spores, which identify soil-forming processes (Fig. 6).

Stage 2. This zone is characterized by spreading of abandoned land after the termination of human activity. The role of herbs (NAP $-60.2 \%$ ) increases significantly. Consolida type, which has been present in this phase both in natural Abies-Fagus forests, so in crops, as well as in all open spaces. The values of the ruderal herbs increased (Chenopodiaceae, Asteraceae). A break in human activity was definitely related to village depopulation. The most intensive migrations, which caused the drastic depopulation of the Ochotnica village was registered during the $3^{\text {rd }}$ Northern War (1700-1721) (Czajka, 1987). However, a successive re-growth in population had been registered from 1758 and resulted in the overpopulation of the village (Czajka, 1987).

Stage 3. (second phase of human activity). The pollen spectra are fixed, but the appearance of the modern secondary Picea-Pinus forests is visible. Human presence is shown by increased values of the ruderal herbs such as the Artemisia, Chenopodiaceae, Urtica Plantago media/major. The beginning of the human activity phase was radiocarbon dated at $1450-1530$ and $1540-1640 \mathrm{cal}$ $\mathrm{AD}$, which, when compared to the dates of the base of the mineral cover, seems to be over-aged probably due to washing out (dissecting) of the lower horizons of the soil profile registering the forest clearing. Redeposition of the sediments can be inferred from the pollen sequence, which is almost identical with that of horizon 1 (see Fig. 6- compare stages 1-3) as well as from a re-appearance of Funghi spores in the profile. It cannot be excluded that the redeposition and acceleration of mineral sediments supply to the basin was associated with the introduction of root and bulb plants (mainly potatoes) in the $19^{\text {th }}$ century (see Czajka, 1987).

The radiocarbon dates (although inverted in the profile) and palynological examination would suggest that the deposition took place during the burning land management combined with forest clearing. In the profile, two periods of plant cultivation and pasturing on the north-facing slope in the closest surrounding of the landslide with the lake-mire basin were recorded. As previously mentioned, two cultivation-pasturing phases are separated by a period without farming, but with restoration of forest and meadow communities.

Basing the chronology on radiocarbon datings and historical records, the period of Wallachian shepherds expension and new settlement formation in the $16^{\text {th }}$ and $17^{\text {th }}$ centuries (Babieniec settlement) was presumably the first phase. The second phase of agricultural usage of the northern slopes was likely in the period of overpopulation and land yearning as well as of the first waves of migrations occurring from the end of the $18^{\text {th }}$ century throughout the $19^{\text {th }}$ century. This is clearly registered in the neighbouring Podhale region (Górka, 1995).

Three sandy inserts in the entire section provide evidence for downpours and formation of the cone below the erosional trough. These processes were characteristic of the humid and cool phase of the Little Ice Age (Grove, 1988; Kotarba, Ed. 2004).

\section{CONCLUSIONS}

Human activity registered in the minerogenic mire or Iwankowskie Lake formed from the Subboreal/Subatlantic Phase (2.49 ka BP) is characterised by significant temporal changes. The oldest stage of agricultural human activity recorded in the pollen diagram was probably associated with the early phase of Slavonic settlement, i.e. Prague province culture. The level in 
which cereal pollen (Cerealia undiff.) appears was radiocarbon dated at 590-770 cal AD which forms the basis for archaeological prospecting of these regions towards looking for traces of early-Slavonic settlements in the Gorce region. The younger phases of human activity are clearly registered in mineral sediments and were associated with agricultural use of the valley sides of Ochotnica River in the last 300-350 years. Intensification of human activity also resulted in a permanent change in sedimentary environment in the surrounding of the mire. Superposition of slopewash during fundamental restructuring of land use when the Gorce were under Walachain colonization and an increase in climate humidity during the Little Ice Age caused the organic accumulation in the mire, which was replaced with mineral sedimentation, formation of mineral cover, erosional removal of some deposits and hiatus development in the base part of the cover. The site occupying the north-facing slope is located $150 \mathrm{~m}$ above the bottom of the river valley. Likely because of that, on gentle fragments of the slopes in the surroundings of the mire (mainly in the topping mineral cover), human activity was characterized by a high temporal variability of land use forms: from cereal (Cerealia undiff.) cultivation associated with the Walachain settlement to tentative discontinuing of agricultural practices and the shift from cereal cultivation in favour of pasturing (or growing root and bulb plants).

Clear traces of human activity, identified in the deposits overlying the peat-filled basin developed over the landslide, originate from recent centuries, the era when overpopulation forced people to expand with agricultural practices and pasturing on highly elevated north-facing slopes. This is confirmed by $\mathrm{C}^{14}$ dates from deposits of the mineral cover.

\section{ACKNOWLEDGEMENTS}

The study was funded by the National Research Centre in framework of grant NCN no. NN 306659940 (2011-2014) and of grant NCN no. NN 305522738 (2010-2015)

\section{REFERENCES}

Adamczyk MJ, 1996. Gorce w latach 1670-1870 i zmiany w ich krajobrazie. Wierchy 62: 93-118 (in Polish).

Adamczyk B and Komornicki T, 1969. Charakterystyka gleboznawcza dolin potoków Jaszcze i Jamne. (The soils of the Jaszcze and Jamne valleys). Studia Naturae, A, 3: 102-153 (in Polish).

Alexandrowicz SW, 1996. Stages of increased mass movements in the Carpathians during the Holocene. Kwartalnik AGH Geologia 22(3): 223-262 (in Polish, English summary).

Alexandrowicz SW, 1997. Holocene dated landslides in the Polish Carpathians. In: Frenzel B, ed., Rapid mass movement as a source of climatic evidence for the Holocene. Palaeoclimate Research 19: 75-83.

Ballantyne CK, 2002. Debris flow activity in the Scottish Highlands: temporal trends and wider implications for datings. Studia Geomorfphologica Carpatho-Balcanica 36: 7-27.
Battaglia S, Leoni L and Sartori F, 2002. Mineralogical and grain size composition of clays developing calanchi and biancane erosional landforms. Geomorphology 49(1-2): 153-170, DOI 10.1016/S0169-555X(02)00171-X.

Baumgart-Kotarba M and Kotarba A, 1993. Late Glacial and Holocene lacustrine sediments of the Lake Czarny Staw Gąsienicowy in the Tatra Mountains. Dokumentacja Geograficzna 4-5: 9-30 (in Polish, English summary).

Behre KE, 1981. The interpretation of anthropogenic indicators in pollen diagrams. Pollen et Spores, N 23(2).

Berglund BE and Ralska-Jasiewiczowa M, 1986. Pollen analysis and pollen diagrams. [In:] B. Berglund, Ralska-Jasiewiczowa M (Eds.) Handbook of Holocene Palaeogeography and Palaehydrology. J. Wiley \& Sons LTD, Chichester-Toronto: 455-484.

Birks HJB, 1979. Numerical methods for the zonation and correlation of biostratigraphical data. In: Berglund BE, ed, Palaeohydrological changes in the temperature zone in the last 15000 years. IGCP 158B. Lake and environments. Project Guide 1, Lund: 99-123.

Birks HJB, 1986. Numerical zonation, comparison and correlation of Quaternary pollen-stratigraphical data. In: Berglund BE, ed., Handbook of Holocene Palaeoecology and Palaeohydrology. J. Wiley \& Sons, Chichester: 743-774.

Bobrov AA, Charman DJ and Warner BG, 1999. Ecology of testate amoebae (Protozoa: Rhizopoda) on peatlands in western Russia with special attention to niche separation in closely related taxa. Protist 150(2): 125-136.

Bortenschlager S, 1982. Chronostratigraphic Subdivision of the Holocene in the Alps. Striae 16: 75-79.

Bronk Ramsey C, 2009. Bayesian analysis of radiocarbon dates. Radiocarbon 51(1): 337-360.

Brown AG., 2009. Colluvial and alluvial response to land use change in Midland England: An integrated geoarchaeological approach. $\mathrm{Ge}$ omorphology $\quad 108(1-2)$ : $\quad 92-106, \quad$ DOI 10.1016/j.geomorph.2007.12.021.

Bucała A, 2012. Contemporary environmental changes of Jaszcze and Jamne Stream Valleys in the Gorce Mountains. Prace Geograficzne IGiPZ PAN 231: pp. 146 (In Polish, English summary).

Bucała A, 2014. The impact of human activities on land use and land cover changes and environmental processes in the Gorce Mountains (Western Polish Carpathians) in the past 50 years. Journal of Environmental Management 138: 4-14, DOI 10.1016/j.jenvman.2014.01.036.

Burtan J, Paul Z, Watycha L, 1978. Szczegółowa Mapa Geologiczna Polski 1: 50 000, arkusz Mszana Górna. (Detailed Geological Map of Poland, 1: 50 000, sheet Mszana Górna), PGI Warszawa (in Polish).

Czajka S, 1987. Ochotnica - dzieje gorczańskiej wsi 1416-1986 (Ochotnica - the history of Gorces' village between 1416-1986). Wyd. Karkonoskie Towarzystwo Naukowe, Jelenia Góra, pp. 367 (in Polish).

Dapples F, Lotter AF, Van Leeuwen JFN, Van Der Knapp WO, Dimitriadis S and Oswald D, 2002. Palaeolomnological evidence for increased landslide activity due to forest clearing and land-use since 3600 cal BP in the western Swiss Alps. Journal of Paleolimnology 27(2): 239-248, DOI 10.1023/A:1014215501407.

Dikau R, Brunsden D, Schrott L and Ibsen ML, Eds., 1996. Landslide recognition. Identification, Movement and Causes. J. Wiley \& Sons: $251 \mathrm{pp}$.

Dobrowolski K, 1936. Studia nad kulturą pasterską w Karpatach północnych (The studies on pastures culture in the North Carpathians region). Wierchy 16: 7-45 (In Polish).

Erdtman G, 1943. An introduction to Pollen Analysis. Chronica Botanica, Waltham, Massachussets: $230 \mathrm{pp}$.

Flizak S, 1966. Polany w Gorcach i Beskidzie Wyspowym. (Glades in the Gorce and Beskid Wyspowy Mountains). Wierchy 35: 159-168 (in Polish)

Folk RI and Ward WC, 1957. Brazos River bar: a study in the significance of grain size parameters. Journal Sedimentary Petrology 27(1): 3-26.

Frenzel B, 2000. Datiert der klimawirksame Eingriff des Menschen in den Haushalt der Natur erst aus dem beginnenden Industriezeit- 
alter? [in:] Entwicklung der Umwelt seit der letzten Eiszeit. Rungespräche der Kommission für Ökologie Dated climatic changes caused by human impact on natural environment since the teginning of the Industrial Eppoch [in:] Development of the environment since the last Ice Age. 18: 33-46, München. (in German)

Gil E, Gilot E, Kotarba A, Starkel L and Sszczepanek K, 1974. An Early Holocene landslide in the Beskid Niski and its significance for palaeogeographical reconstructions. Studia Geomorphologica Carpatho-Balcanica 8: 69-83.

Górka Z, 1995. Osadnictwo. [In:] J. Warszyńska (Ed.) Karpaty Polskie, (Settlement [In:] J. Warszyńska (Ed.) The Polish Carpathians). Uniwersytet Jagielloński, Kraków: 219-232 (in Polish).

Górz B, 1994. Rolnictwo Podhala. [w:] Studia nad przemianami Podhala. B. Górz (red.) (Agriculture of the Podhale, Studies of the changes in the Podhale), Prace Monograficzne WSP $w$ Krakowie, 172: 142-176 (in Polish)

Grove J, 1988. The Little Ice Age. Methuen, London-New York: 1-479.

Heiri O, Lotter AF and Lemcke G, 2001. Loss on ignition as a method for estimating organic and carbonate content in sediments: reproducibility and comparability of results. Journal of Paleolimnology 25(1): 101-110, DOI 10.1023/A:1008119611481.

Hess M, 1965. Piętra klimatyczne w polskich Karpatach Zachodnich (Climatic vertical zones in the Polish Western Carpathians). Zeszyty Naukowe UJ, Prace Geograficzne 11: 12-67 (in Polish).

Kabailene M, 1969. Formation of pollen spectra and the methods of paleovegetation reconstruction. Vilnius. pp.148.

Kalicki T and Krąpiec M, 1995. Problems of Datong alluvium Rusing buried subfossil tree trunk: lesson from the „black oaks” of the Vistula Valley, Central Europe. The Holocene 5(2): 243-250, DOI $10.1177 / 095968369500500213$.

Karlen W and Kuylenstierna J, 1996. On solar forcing on Holocene climate: evidence from Scandinavia. The Holocene 6(3): 359-365, DOI 10.1177/095968369600600311.

Koperowa W, 1962. Późnoglacjalna i holoceńska historia roślinności Kotliny Nowotarskiej, (The history of the Late-Glacial and Holocene vegetation of the Nowy Targ Basin) Acta Paleobotanica 2, 3: 3-45 (in Polish, English summary).

Kołaczek P, Fijałkiewicz-Kozieł B, Karpińska-Kołaczek M and Gałka $\mathrm{M}, 2010$. The last two millennia of vegetation development and human activity in the Orawa-Nowy Targ Basin (South-Eastern Poland). Acta Palaeobotanica 50(2): 133-148.

Kotarba A, (Ed.), 2004. Rola małej epoki lodowej w przekształceniu środowiska przyrodniczego Tatr. (Effect of the Little Ice Age on transformation of natural environment of the Tatra Mountains). Prace Geograficzne IGiPZ PAN 197: pp. 116 (in Polish, English summary).

Kovalyukh N, Petrenko L and Kovalenko V, 1996. Geochronology of nival-glacial deposits of the Ukrainian Carpathians Mountains. Geochronometria 14: 111-119.

Kulka A, Rączkowski W, Żytko K, Gucik S and Paul Z, 1987. Szczegółowa Mapa Geologiczna Polski 1: 50 000, arkusz SzczawnicaKrościenko (Detailed Geological Map of Poland, 1: 50 000, sheet Szczawnica-Krościenko), PGI Warszawa (in Polish).

Kurzeja M, 2006. Historia osadnictwa (Settlement history) [in:] W. Różański [Ed.] Gorczański Park Narodowy, 25 lat ochrony dziedzictwa przyrodniczego $i$ kulturowego Gorców. Wyd. Kartograficzne Kompas, Poręba Wielka: 207-212 (in Polish).

Krapiec M, 1992. Late Holocene tree-ring chronology of south and Central Poland (in Polish with English sum.). Kwartalnik AGH, Geologia 18(3): 37-119.

Latałowa M, Ralska-Jasiewiczowa M, Miotk-Szpoganowicz G, Zachowicz J and Nalepka D, 2004. Fagus sylvatica L. - Beech. In: Ralska-Jasiewiczowa M, Latałowa M, Wasylikowa K, Tobolski K, Madeyska E, Wright H.E. Jr and Turner C (Eds.), Late Glacial and Holocene history of vegetation in Poland based on isopollen maps. W. Szafer Institute of Botany, Polish Academy of Sciences, Kraków: 95-104.

Madyda-Legutko R, 1996. Zróżnicowanie kulturowe polskiej strefy beskidzkiej w okresie lateńskim i rzymskim (Cultural diversity of Polish Beskidy Zone during La Tene and Roman Periods). Wy- dawnictwa Uniwersytetu Jagiellońskiego, Kraków: 166 pp. (in Polish, German summary).

Madyda-Legutko R and Tunia K, 1993. Rytro-karpacka osada z okresu wędrówek ludów (Rytro-Carpathian settlement from the Migration Period). Zeszyty Naukowe U.J., Prace Archeologiczne 57: 148.

Magny M, 1993. Holocene fluctuation of lake levels in the French Jura and sub-Alpine ranges, and their implications for past general circulation pattern. The Holocene 3(4): 306-313, DOI $10.1177 / 095968369300300402$.

Magny M, 2004. Holocene climatic variability as reflected by mid European lake-level fluctuation and its probable impact on prehistoric human settlements. Quaternary International 113(1): 65-79, DOI 10.1016/S1040-6182(03)00080-6.

Mangerud J, Andersen ST, Berglund BE and Donner J, 1974. Quaternary stratigraphy of Norden, a proposal for terminology and classification. Boreas 3(3):109-126, DOI 10.1111/j.15023885.1974.tb00669.x.

Margielewski W, 1997. Protection of landslide dew ponds above Ochotnica Górna (Lubań Range). Chrońmy Przyrodę Ojczysta 53(4): 74-84 (in Polish, English summary).

Margielewski W, 1998. Landslide phases in the Polish Outer Carpathians and their relation to climatic changes in the Late Glacial and the Holocene. Quaternary Studies in Poland 15: 37-53.

Margielewski W, 2000. Economical role of the landslides in the Beskid Makowski Mts. Problemy Zagospodarowania Ziem Górskich 46: 15-34 (in Polish, English summary).

Margielewski W, 2006. Records of the Late Glacial-Holocene palaeoenvironmental changes in landslide forms and deposits of the Beskid Makowski and Beskid Wyspowy Mts. area (Polish Outer Carpathians). Folia Quaternaria 76: 1-149.

Margielewski W and Kovalyukh N, 2003. Neoholocene climatic chan ges recorded in landslides' peat bog on Mount Ćwilin (Beskid Wyspowy Range, Outer Carpathians). Studia Geomorphologica Carpatho-Balcanica 37: 59-76.

Margielewski W, Krąpiec M, Valde-Nowak P and Zernitskaya V, 2010a. A Neolithic yew bow in the Polish Carpathians. Evidence of the impact of human activity on mountainous palaeoenvironment from the Kamiennik landslide peat bog. Catena 80(3): 141153, DOI 10.1016/j.catena.2009.11.001.

Margielewski W, Michczyński A and Obidowicz A, 2010b. Records of the Middle- and Late Holocene palaeoenvironmental chan ges in the Pcim-Sucha landslide peat bogs (Beskid Makowski Mts., Polish Outer Carpathians). Geochronometria 35: 11-23, DOI 10.2478/v10003-010-0009-1.

Medwecka-Kornaś A, 1968. Zbiorowiska roślinne dolin Jaszcze i Jamne [in:] A. Medwecka-Kornaś [Ed.] Doliny potoków Jaszcze i Jamne w Gorcach. (Plant communities in the Jaszcze and Jamne Valleys [in:] A. Medwecka-Kornaś [Ed.] The Jaszcze and Jamne valleys in the Gorce Mountains). Studia Naturae A, 2: 49-91 (in Polish).

Moore PD, Webb JA and Collinson ME, 1991. Pollen analysis. Blackwell Scientific, Oxford: 1-216.

Mycielska-Dowgiało E and Rutkowski J, eds., 1995. Researches of Quaternary sediments. Some methods and interpretation of the results. Warszawa, Wydziat Geografii i Studiów Regionalnych UW: 356 pp. (in Polish)

Nowalnicki T, 1976. Jeziorka osuwiskowe w Beskidzie Sądeckim (Landslides' lakes in the Beskid Sądecki Mts.). Wierchy 45: 182198 (In Polish)

Obidowicz A, 1989. Type region P-a: Inner Western Carpathians Nowy Targ Basin. [In:] Environmental changes recorded in lakes and mires of Poland during the last 13000 years, Part three. Acta Palaeobotanica 29(2): 11-15.

Obidowicz A, 1990. Eine pollenanalytische Und moorkundliche Studie zur Vegetationsgeschichte des Podhale-Gebietes (West-Karpaten). (Palinological and peat-bog studies on the vegetation changes of the Podhale Region (Western Carpathians)). Acta Palaeobotanica 30(1-2): 147-219 (In German).

Obidowicz A and Margielewski W, 2008. Problematyka klasyfikacji torfowisk górskich (Problems of mountainous peat bogs classification). In: Żurek S, ed., Torfowiska gór i Wyżyn. Uniwersytet im. $J$. Kochanowskiego, Kielce :103-109 (in Polish). 
Obidowicz A, Szczepanek K, Madeyska E and Nalepka D, 2004. Abies alba Mill. - Fir. In: Ralska-Jasiewiczowa M, Latałowa M, Wasylikowa K, Tobolski K, Madeyska E, Wright H.E. Jr and Turner C (Eds.), Late Glacial and Holocene history of vegetation in Poland based on isopollen maps. W. Szafer Institute of Botany, Polish Academy of Sciences, Kraków: 31-38.

Obidowicz A, Madeyska E and Turner C, Eds. 2014. Postglacial history of vegetation in the Polish part of the Western Carpathians based on isopollen maps. W. Szafer Institute of Botany Polish Academy of Sciences, Kraków (in press).

Obrębska-Starklowa B, 1969. Stosunki mikroklimatyczne na pograniczu pięter leśnych i pól uprawnych w Gorcach.( Microclimatic relationships on the borderland of forest and cultivated field zones in the Gorce Mountains). Zeszyty Naukowe UJ, Prace Geograficzne 23: pp. 141.

Okuniewska-Nowaczyk I, Milecka K, Makohonienko M, Harmata K, Madeja J and Nalepka D, 2004. Secale cereale L. - Rye. In: Ralska-Jasiewiczowa M, et al. eds., Late Glacial and Holocene history of vegetation in Poland based on isopollen maps. W. Szafer Institute of Botany PAS, pp 347-349.

Opravilovà V and Hàjek M, 2006. The variation of testacean assemblages (Rhizopoda) along the complete base-richness gradient in fens: a case study from the western Carpathians. Acta Protozool. 45: 191-204.

Pánek T, Hradecký J, Smolková V, Šilhán K, Minár J and Zernitskaya $\mathrm{V}, 2010$. The largest prehistoric landslide in northwestern Slovakia: Chronological constrains of the Kykula long-runout landslide and related dammed lakes. Geomorphology 120(3-4): 233247, DOI 10.1016/j.geomorph.2010.03.033.

Pánek T, Smolková V, Hradecký J, Baron I and Šilhán K, 2013. Holocene reactivations of catastrophic complex flow-like landslides in the Flysch Carpathians (Czech Republic/Slovakia). Quaternary Research 80(1): 33-46, DOI 10.1016/j.yqres.2013.03.009.

Parczewski M, 1988. Najstarsza faza kultury wczesnosłowiańskiej w Polsce (The oldest phase of the Early Slavonic Culture in Poland). Rozprawy habilitacyine 141, Jagiellonian University Kraków.

Paul Z, 1980. Szczegółowa Mapa Geologiczna Polski 1: 50 000, Arkusz Łacko (Detailed Geological Map of Poland, 1: 50 000, sheet Łącko), PGI Warszawa.

Pettijohn FJ, 1975. Sedimentary Rocks. 3rd ed. New York, Harper and Row: $628 \mathrm{pp}$.

Ralska-Jasiewiczowa M, ed., 1989. Environmental changes recorded in lakes and mires of Poland during the last 13000 years, Part III, Acta Palaeobotanica 29: 1-120.

Ralska-Jasiewiczowa M, Latałowa M, Wasylikowa K, Tobolski K, Madeyska E, Wright HE and Turner C (Eds.), 2004. Late Glacial and Holocene history of vegetation in Poland based on isopollen maps. W. Szafer Institute of Botany, Polish Academy of Sciences, Kraków 1-444.

Reille M, 1992. Pollen et spores d'Europe et d'Afrique du nord. (Pollen and spores of the Europe and the Northern Africa). Laboratoire de Botanique historique et Palynologie, Marseille: 1-543.

Reimer PJ, Bard E, Bayliss A, Beck JW, Blackwell PG, Bronk Ramsey C, Buck CE, Cheng H, Edwards RL, Friedrich M, Grootes PM, Guilderson TP, Haflidason H, Hajdas I, Hatté C, Heaton TJ, Hoffmann DL, Hogg AG, Hughen KA, Kaiser KF, Kromer B, Manning SW, Niu M, Reimer RW, Richards DA, Scott EM, Southon JR, Staff RA, Turney C and van der Plicht J, 2013. Intcal13 and Marine13 radiocarbon age calibration curves 050,000 years cal BP. Radiocarbon 55(4): 1869-1887.

Soldati M, Corsini A and Pasuto A, 2004. Landslides and climate change in the Italian Dolomites since the Late Glacial. Catena 55(2): 141-161, DOI 10.1016/S0341-8162(03)00113-9.

Starkel L, 1972. An outline of the relief of the Polish Carpathians and its importance for human management. Problemy Zagospodaro- wania Ziem Górskich 10: 75-150 (in Polish, English summary).

Starkel L, 1977. Paleogeografia holocenu (Holocene's palaeogeography). PWN Warszawa, pp. 1-362 (in Polish)

Starkel L, 1988. Man's activity as a cause of changes of denudation and sedimentation processes in the Holocene. Przeglad Geograficzny 60: 251-265 (in Polish, English summary).

Starkel L, 1989. The evolution of natural environment of Carpathian Mts. During the human management. Problemy Zagospodarowania Ziem Górskich 29: 35-45.

Starkel L, 1995. The pattern of the Holocene climatic variations in Central Europe based on various geological records. Quaestionaes Geographicae, Special Issue 4: 259-264.

Starkel L, 1997. Mass movement during the Holocene: Carpathian example and the European perspective. In: Frenzel B., ed., Rapid mass movement as a source of climatic evidence for the Holocene. Palaeoclimate Research 19: 385-400.

Starkel L, 1999. Chronostratigraphy of Late Vistulian and Holocene in Poland. In: Pazdur A, Bluszcz A, Stankowski A, and Starkel L, eds., Geochronologia górnego czwartorzędu Polski, w świetle datowania radioweglowego $i$ luminescencyjnego, WIND, Wrocław: 280-283 (in Polish).

Starkel L, 2002. Change in the frequency of extreme events as the indicator of climate change in the Holocene (in fluvial systems). Quaternary International 91(1): 25-32, DOI 10.1016/S10406182(01)00099-4.

Starkel L, Kalicki T, Krapiec M, Soja R, Gębica P and Czyżowska E 1996. Hydrological changes of valley floor in the Upper Vistula Basin during Late Vistulian and Holocene. In: Starkel L., ed., Evolution of the Vistula river Valley during the last 15000 years, $p$. $I V$, Geographical Studies Special Issue 9: 1-128.

Starkel L, Soja R and Michczyńska DJ, 2006. Past hydrological events reflected in Holocene history of Polish Rivers. Catena 66(1-2): 24-33, DOI 10.1016/j.catena.2005.07.008.

Starkel L, Michczyńska D, Krapiec M, Margielewski W, Nalepka D and Pazdur A, 2013. Holocene chrono- climatostratigraphy of Polish territory. Geochronometria 40(1): 1-21, DOI 10.2478/s13386012-0024-2.

Tunia K, 1992. Środowiskowe uwarunkowania osadnictwa z pierwszych wieków naszej ery w Karpatach Zachodnich (Environmental condition of the settlements of 1 st centurie AD in the Western Carpathians). Sprawozdania z Posiedzeń Komisji Naukowych PAN, Kraków 36 (1-2): 295-297 (in Polish).

Valde-Nowak P, 1988. Etapy i strefy zasiedlania Karpat polskich w neolicie i na poczatku epoki brazu (Stages of colonisation of the Polish Carpathians in the Neolithic and Early Bronze eppochs). Zakład Narodowy im. Ossolińskich, Wrocław (in Polish).

Valde-Nowak P, 1995. Stone source from the North-Carpathian Provence in the Stone and Early bronze Ages. Archaeologia Polona 33: $111-118$

Valde-Nowak P, 2000. Dzieje osadnictwa (History of settlement) In: Staszkiewicz J, Alexandrowicz Z, Wieczorek T and Witkowski Z, (Eds.), Przyroda Popradzkiego Parku Krajobrazowego: 81-90. Popradzki Park Krajobrazowy Publ. Stary Sącz 2000. (in Polish)

Wentworth CK, 1922. A scale of grade and class terms for clastic sediments. Journal of Geology 30(5): 377-392.

Zuchiewicz W, 2010. Neotektonika Karpat polskich i zapadliska przedkarpackiego (Neotectonic of the Polish Carpathians and Carpathian Foredeep), AGH ed., pp. 234 (In Polish).

Żurek S and Pazdur A, 1999. Zapis zmian paleohydrologicznych w rozwoju torfowisk Polski (Records of palaeohydrological changes in peat bogs of Polish Territory). In: Pazdur A, Bluszcz A, Stankowski A, and Starkel L, eds., Geochronologia górnego czwartorzędu Polski, $w$ świetle datowania radiowęglowego i luminescencyjnego, WIND, Wrocław: 215-228 (in Polish). 